\title{
A CULTURA DO MEDO E AS TENSÕES DO VIVER A CIDADE: NARRATIVA E TRAJETÓRIA DE VELHOS MORADORES DE PORTO ALEGRE ${ }^{1}$
}

Cornelia Eckert $^{2}$

\section{Introdução}

Este artigo trata do cotidiano de velhos habitantes de Porto Alegre, a partir da suas reconstruções narrativas das experiências temporais que delineiam trajetórias de vida. Refere-se a uma população de segmentos médios que de alguma forma experienciou as transformações urbanas da localidade e compartilhou de interpretações sócio-históricas e políticas a partir de inúmeras modalidades de simbolização: meios de comunicação de massa, formas de sociabilidade formais e informais, etc.

Tomamos as narrativas como sendo a maneira singular de problematizar o caráter temporal de suas experiências de vida, exteriorizando valores interiorizados cotidianamente pelo sujeitonarrador, evidenciando a complexidade das tramas cotidianas de inserção nos contextos sociais, da negociação dos papéis e performances demandados e do desempenho no ato comunicativo/vivido. Trata-se de "redescobrir a autenticidade do sentido graças a um esforço de desmistificação", nos termos de Paul Ricoeur, tentando compreender o que descreve, para descobrir seu sentido, um método, portanto hermenêutico ou interpretativo" (Japiassu In Ricoeur, 1988: 3-4).

A narrativa da experiência que analisamos, neste artigo, dizem respeito a configuração de uma cultura do medo na cidade a partir do trabalho da memória, evocando no presente suas experiências que processam as feições dos medos assimiláveis aos "dramas culturais” (Turner, 1974), na tentativa de exprimir, o sentido "dizível” da existência e da vida, tecendo na memória narrativa um sentido cultural que ultrapasse o caráter episódico de experiências vividas.

Em seus relatos, contrastam um cenário de violência no tempo atual com lembranças do

\footnotetext{
1 Artigo relacionado a pesquisa Cnpq "Estudo antropológico de itinerários urbanos, memória coletiva e formas de sociabilidade no mundo urbano contemporâneo" desenvolvida em Porto Alegre sob minha coordenação e da antropóloga Dra. Ana Luiza Carvalho da Rocha no Banco de Imagens e Efeitos Visuais, PPGAS/UFRGS, iniciada em 1997. De 33 entrevistas realizadas até 1999 (22 gravadas em K-7 e 11 em vídeo digital, transcritas), 18 foram realizadas com pessoas com mais de 60 anos até 87 anos; 9 entrevistas foram realizadas com pessoas entre 40 a 60 anos; 6 entrevistas foram realizadas com pessoas de 20 a 40 anos. Os entrevistados pertencem na sua maioria a segmentos médios, mas também desenvolvemos pesquisa junto a uma população de baixa renda, moradores de vilas na periferia. Neste artigo analisamos as entrevistas com pessoas de mais de 60 anos. Agradeço a Maria Cecília de Souza Minayo e Carlos E. A Coimbra Jr. as sugestões elaboradas por ocasião da Oficina de trabalho "Antropologia, Saúde e Envelhecimento" (Rio de Janeiro, agosto 2000). Agradeço igualmente a Clarissa Eckert Baeta Neves e Ana Luiza Carvalho da Rocha pela leitura atenciosa e proveitosa discussão do texto.

2 Professora do Departamento e PPG Antropologia Social, Universidade Federal do Rio Grande do Sul.
} 
passado, abordando de múltiplas formas o tema do medo, mapeando nos jogos descontínuos/contínuos de suas representações, imagens da cidade-contexto em que constroem sua “identidade como geração" (Lins de Barros, 1995:92). No processo de atualizar suas interpretações sobre a cidade que contextualiza suas experiências de vida, as feições dos medos tomam múltiplas colorações. Nesse repertório simbólico de viver numa cidade violenta, não raro reafirmam as representações envoltas por um discurso de "poder" sobre o agravamento das situações de violência e uma dinâmica criminal, sobretudo divulgado pela mídia.

As notícias restritas às características de criminalidade certamente não cobrem toda a complexidade da problemática da violência urbana no mundo contemporâneo, onde devemos considerar uma gama ampla de aspectos impactantes à qualidade de vida: problemas historicamente mais recentes ou mais antigos, como a poluição do ecossistema, o desemprego, a miséria, a corrupção, as disputas por poder doméstico e/ou público (violência doméstica, rivalidade entre gangues, disputas por honra familiar, etc) que geram violência e vítimas fatais.

Mas entre todos, são os crimes que transformam os habitantes em vítimas em potencial, como o crime contra o patrimônio e os crimes contra a pessoa "em que o agressor faz uso da força para causar dano a alguém" (Tirelli, 1996: 29), que são considerados os componentes que englobariam os demais em níveis de significação na formação de uma "cultura do medo"3.

As pessoas são roubadas, assaltadas, agredidas, etc. Esses acabam sendo os maiores temores e as indagações reflexivas cotidiana de segmentos médios urbanos destituídos da liberdade celebrada na modernização. Vítimas ou não de perigos reais (incidentes/acidentes), adotam estratégias de proteção e criticam a insustentabilidade da ordem cotidiana por autoridades civis.

Estudos e reportagens constatam que não raro quando se questiona sobre as causas da violência urbana, no imaginário da população urbana a tendência é conceber o "inimigo" na figura genérica do "pobre bandido", o "outro", que ameaçaria uma irreversibilidade na crise urbana. O deslize para um sistema de acusações é perigo ideológico iminente. ${ }^{4}$

Neste sentido é a população do segmento médio brasileiro, que sempre buscou proteger seu patrimônio num contexto fragilizado pelas desigualdades sociais, que hoje mais se depara com o aumento da violência urbana como um "neo-conflito" (Ricoeur 1988: 149), uma nova determinação social pelo risco iminente em sua rotina da ameaça à sobrevivência física pela criminalidade

\footnotetext{
${ }^{3}$ Nos termos de Soares, "uma certa estrutura simbólica de articulação entre representações” (Soares et alli, 1996:259).

${ }^{4}$ Citamos como exemplo a reportagem "A centrífuga do medo na cidade" na Revista Veja. O artigo de Dorrit Harazim analisa que "como um véu que impede a percepção dos verdadeiros problemas, a paranóia social do rico confunde medo com pobre". Revista Veja, 23 de novembro 1994. p.78.
} 
desmesurada em que transparece a globalização do crime organizado. Cada vez mais recolhidos em seus nichos gradeados conclamam por macrossoluções enquanto mergulham no sentimento de impotência, sem sair da passividade.

Porto Alegre ${ }^{5}$, neste final de século, é uma polis, uma urbs, enfim uma metrópole com seus quase 1.500.000 habitantes. Sua modernidade vem sendo figurada em logotipos, funções e status como a "capital do Mercosul", primeiríssimo lugar em qualidade de vida entre as demais capitais brasileiras. Sua imagem internacional é, hoje, a de "cidade democrática", inserida na civilidade apregoada pelos ideais da Razão; o progresso por um lado, e os ideais do individualismo por outro.

Uma análise dos conteúdos dos jornais gaúchos (de 1997 a 2000) permite observar, no entanto, que eles sistematicamente repetem matérias que prognosticam que o Rio Grande do Sul está "doente", está "enfermo" ou que "a violência mandou o Estado para a enfermaria", ocupando o Estado hoje, conforme o Ministério de Justiça, o segundo lugar no ranking nacional de vitimização, passando à frente do Rio de Janeiro nesta desmeritosa quantificação, perdendo apenas para São Paulo, que tem uma população 3,6 vezes maior. ${ }^{6}$

“O ano 2000 nasce batizado pela violência crescente', divulga a imprensa denunciando uma "explosão de violência" sem par no Estado e em destaque na cidade de Porto Alegre. A população é roubada na rua, em automóveis, nos ônibus, no trabalho e em casa, colocando "um Estado que se orgulha de sua qualidade de vida, nos níveis das regiões mais violentas do país"7. "O crime desafia autoridades" destacam as manchetes sobre a violência local ao longo do século ${ }^{8}$.

As reportagens analisadas indicam que os moradores porto alegrenses (em sua maioria de segmentos médios) estão amedrontados e revoltados contra a falta de atitude dos poderes dirigentes sobre uma política mais ostensiva e protetora contra o crime organizado, o tráfico de drogas, o crime contra o patrimônio, etc.

Os dados jornalísticos delineiam um mapa de inseguranças no Estado onde a violência seria a epidemia contagiosa de uma desordem que situa o indivíduo e a coletividade num processo de aceleramento de transformações históricas geradoras de inquietações e angústias coletivas.

O conteúdo destas reportagens emprestam um clima ainda mais caótico quando comparadas com as seções dedicadas a re-noticiar o passado porto alegrense destacando, no "túnel do tempo",

\footnotetext{
${ }^{5}$ Porto Alegre, Fonte IBGE, 1996: população 1.286.251 habitantes; expectativa de vida 70,3 anos; mortalidade infantil 18 por 1000 habitantes; população alfabetizada, $91 \%$.

${ }^{6}$ Vítimas da Insegurança. "As seqüelas da violência”. Jornal Zero Hora. Porto Alegre, 23 julho 2000.p. 44. Os gaúchos, segundo esta reportagem, sofreram 48.710 lesões corporais no primeiro semestre de 1999 enquanto que no Rio de Janeiro foram registrados 325 casos a menos. Entram nessa contabilidade agressões como socos, facadas, garrafadas e tiros. Reportagem de Patrícia Specht.

${ }^{7}$ Zero Hora, Porto Alegre, 31 de outubro de 2000. p. 3.

${ }^{8}$ Zero Hora, Porto Alegre, 20 de agosto de 2000. p. 44 e 45. Reportagem de Carlos André Moreira.
} 
um clima urbano dos anos 50 a 70 ritmado por referências humanitárias quando "existia um equilíbrio entre a vida familiar e a coletiva". O culto à ordem no passado recente destaca os segmentos médios que valorizariam o convívio familiar, quando sentiam-se seguras para ocupar as ruas do centro com destaque para os foottings na rua da Praia ${ }^{9}$, as festas e os concertos no Parque da Redenção, para as reuniões nas calçadas, para as rodas de chimarrão ao entardecer, temas de predileção de cronistas e poetas do passado.

São sobretudo os velhos habitantes que testemunham de forma privilegiada estas passagens descontínuas do tempo, as mudanças que tematizam as crises como vividas, constitutivas de sistemas de representações e de valores em vigor em todas as ações e práticas cotidianas.

Neste sentido sugerimos que os entrevistados, ao refletirem sobre a crise dos tempos na cidade, re-situem sua própria identidade de ser cidadão neste contexto, configurando a construção de sua identidade citadina como um processo de crise de identidade. Mas esta reflexão sobre a identidade emblemática do ser porto alegrense é encompassada pela interpretação da passagem do tempo, a partir de uma trajetória de envelhecimento do eu e transformações de valores geracionais, no âmbito em que a noção do eu é repensada da mesma forma que se confrontam com outros imperativos socialmente determinantes, como o de apreenderem-se como "idosos" numa cidade violenta, uma vez que "o curso da vida é construído em termos da necessidade antecipada de confrontar e resolver essas fases de crise" (Debert, 1999:53).

Trata-se de pessoas que pertenceram a uma geração que vivenciou estas transições incorporadas no processo de construção social da identidade de pertença. Privilegiamos pois uma idéia de geração que é "menos marcada pela idade das pessoas que a compartilham do que pela vivência de determinados eventos que marcam trajetórias passadas e futuras" (Debert, 1999: 52). ${ }^{10}$

A população analisada define seu estilo de vida como pertencente a segmentos médios ${ }^{11}$, no sentido em que suas trajetórias foram motivadas por projetos de vida cuja condição econômica e social é construída a partir da educação e profissionalização muito mais do que da posse de capital

\footnotetext{
9 "O chamado footing na Rua da Praia, era antigo hábito entre rapazes e moças, que perdurou em Porto Alegre até os anos 60. Consistia em passeios, a determinadas horas, sem maiores compromissos, a não ser tentar algum namoro, ver o movimento ou por simples passatempo". Almanaque Gaúcho, "Túnel do Tempo" de Antônio Goulart. Zero Hora. Porto Alegre, 23 de outubro de 2000. p. 54.

10 "As pesquisas sobre grupos de idade mostram, por um lado, que a geração, mais do que a idade cronológica, é a forma privilegiada de os atores darem conta de suas experiências extrafamiliares; por outro lado, indicam que mudanças na experiência coletiva de determinados grupos não são apenas causadas pelas mudanças sociais de ordem estrutural, mas que estes grupos são extremamente ativos no direcionamento das mudanças de comportamento, na produção de uma memória coletiva e na construção de uma tradição. A idéia de geração, apesar das várias conotações que assume, teria assim uma efetividade que ultrapassa o nível das relações na família, direcionando transformações que a esfera da política tem que incorporar". (Debert, 1999: 52-53).

11 Seguimos os preceitos de Pierre Bourdieu para quem a noção de classe social ou "segmentos médios" deve ser apreendida tanto a partir da posição e situação na estrutura social quanto dos bens simbólicos e do capital cultural referentes às relações entre as classes, uma vez que se relacionam ao mundo representacional que os atores conferem a suas posições de pertencimento. (Bourdieu, 1974).
} 
ou propriedades. Neste sentido constroem,de modo geral, uma auto-imagem de grupo emergente assalariado, adotando perspectivas políticas e gostos diversos a partir de anseios sobre posições sociais que conformam o pensamento contemporâneo até idéias sobre pobreza e direitos de cidadania.

Estes segmentos médios se caraterizam por diferenciações internas complexas de pertencimentos a redes de interesse e grupos morais diversos cuja imagem mais generalizadora pode definir um pertencimento à classe-média "baixa", "média" e "alta" conforme a renda salarial capaz de sustentar uma qualidade de vida que permita a execução de projetos familiares de modernização e ascensão sócio-cultural bem delineados que vão desde a educação base até uma capacidade de financiar hábitos de consumo para além da cesta básica, diferenciando-se, neste sentido, de uma grande maioria de baixa renda. Tal diferença não se vislumbra apenas na renda, mas também nos papéis sociais de autoridade, influência e poder, em geral conquistados a partir de um capital cultural. $^{12}$

A aproximação com os entrevistados partiu da rede de amigos e conhecidos dos familiares de alunos envolvidos na pesquisa, tendo por critério inicial sua residência em bairros centrais há um tempo considerável e sua disponibilidade em receber-nos como pesquisadores indagando sobre suas histórias de vida. Após a concordância, as visitas ocorreram em suas residências. No caso de serem um casal, conversamos com ambos simultaneamente, na maioria das ocasiões. Em alguns casos de entrevistas com vídeo, foram filmados seus percursos de rotinas e situações de convívio nas ruas do bairro.

Entre os entrevistados (que são citados com nomes fictícios neste trabalho), aqueles que não são nascidos em Porto Alegre vieram do interior do Rio Grande do Sul ou de outros Estados para esta capital nos anos 30, 40 ou 50, tendo portanto uma trajetória pessoal significativa nesta cidade. Dentre os entrevistados homens, todos estão hoje aposentados, enquanto as mulheres entrevistadas, a maioria são donas-de-casa, desempenhando tarefas restritas ao círculo doméstico, mas duas também vivem a experiência da aposentadoria, após uma vida ativa de trabalho assalariado como professoras.

12 O antropólogo Gilberto Velho, em sua obra A Utopia Urbana (1989) sobre segmentos médios cariocas, faz uso do conceito de white-collars da obra de Wright Mills, pois é neste mundo "que se deve buscar grande parte do que é característico da vida do século XX” (Mills, 1985:120). 


\section{Narrar a cidade com medo}

Dona Crista tem hoje 92 anos. Mora com familiares em uma casa de alvenaria com pátio em bairro de classe média na cidade de Porto Alegre. Estimulada a refletir sobre sua trajetória de vida, narra longamente sobre sua vida familiar em pequena cidade do interior que contempla sua infância e adolescência. O casamento e a carreira do marido são citados como sendo as motivações para terse mudado para Porto Alegre na década de 30, onde "criou raízes". Iniciamos este artigo com sua voz para trazer, nas suas reminiscências, o jogo contrastivo de um tempo passado e de um tempo atual para ordenar seus sentimentos em relação aos temores do viver na cidade de Porto Alegre hoje.

... Naquele tempo era uma vida bem simples, né, bem pacata, mas num ponto era melhor, não havia violência como há hoje, né. As crianças saíam, brincavam de noite na rua, a gente sentava na calçada. Até tarde da noite. E hoje em dia... Vai sentar na calçada hoje? ... Deus o livre... Vai ficar com a casa aberta sentada na rua? Tá pedindo pra ser assaltada né ... Naquele tempo não, a gente sentava, tomando chimarrão, as vizinhas vinham tudo sentava na frente. Nossa! Quantas horas a gente ficava até a meia noite sentado na frente conversando. Mas capaz que dê pra fazer isso hoje! Mas nunca, né. ... As crianças brincavam na rua de noite, saíam, vinham pra casa. E a gente não tinha preocupação, não havia mesmo, isso é uma pura verdade. Pelo menos onde eu morei. Não tinha essa bandidagem, não tinha mesmo. A gente conhecia as vizinhança, criançada brincavam, de noite saíam, brincavam na rua vinham... Hoje não.. os netos saem e a gente fica preocupada, né. Botou o pé pra fora não sabe se volta. Ai que coisa triste! Eu, cada um que sai eu faço uma carga de oração. De verdade! Cada um que sai eu rezo. Pra que volte sem problemas né. Porque eu acho que tem que ser assim mesmo. Só Deus pra nos salvar. Eu não tenho esperança... Cada vez aumenta mais essas coisa ruim né... Porque era um tempo muito bom, era um tempo com pouco progresso, mas era muito bom por isso. Muita paz... e segurança, a gente não tinha medo das coisas, né. Ladrão era... só de noite arrombando janela das casas e assim mesmo era muito pouco, não tinha assim como tem hoje. Hoje roubam, assaltam de dia. Não, naquele tempo arrombavam uma... "Sabe vizinha, arrombaram a loja do seu fulano, entraram pela janela!" Ah, mas aquilo era uma coisa, um acontecimento! E era uma coisa que acontecia assim lá uma vez que outra, né! Às vezes faziam isso. Faziam buraco na parede pra entrar né. Mas hoje não precisa, entram porta dentro que... (risos) que a gente estranha né. Puxa vida, e como.

Vê hoje que tá tudo povoado. Esses... esses condomínio que eles fizeram aí, essas coisas tudo isso não tinha né. Porto Alegre cada vez cresce mais, fica mais bonita né. Não tinha nada disso... Hoje tá tudo uma beleza. Vai, vai melhorando, cada dia melhor, e o progresso avançou muito ligeiro. Pra esse lado aqui, não sei dos outros porque eu não vou pra lá. Mas pra cá, barbaridade, como desenvolveu. Porque aqui até Alvorada é cidade hoje, é asfaltado e tudo que não era. Era uma poeiragem triste na estrada. Hoje tudo tá que é uma maravilha... Sempre gostei daqui.

O ponto de vista de Dona Crista revela o paradoxo de viver o tempo vertiginoso da cidade moderna que intensifica os estranhamentos e os distanciamentos entre as pessoas nas esferas públicas e nas esferas privadas, construindo rupturas e fragmentações intensas no exercício da arte de conviver. Trata-se da ambigüidade entre os discursos que consolidam uma admiração à racionalidade urbana (o progresso econômico como valor ideológico) e o embaraçamento da experiência vivida pelas crises consubstanciais ao sistema e a imagem da catástrofe total dos valores e virtudes sociais. 
Dona Crista, caracteriza hoje um estilo de viver em Porto Alegre a partir do caos de um tempo presente, reportando ao passado, na sua condição de pertencer à classe média, uma ordem mais sólida. A consciência da desordem vem das sensações de rupturas inéditas e imprevisíveis na sua própria cidade, onde as pessoas empreendem mil maneiras de se protegerem, constroem muros e grades em torno de suas casas e os idosos são recomendados a evitar circular em certos locais, em certos horários: o deslocamento solitário. A experiência de envelhecimento é, cada vez, mais exilada de dinâmicas interativas (o vizinhar, o passeio livre, a caminhada descomprometida), sendo prisioneira do pessimismo sobre os itinerários dos membros da família, restando-lhe a preocupação presenteísta da sobrevivência dos netos que circulam neste contexto urbano hostil, frustrando-lhe o exercício de projetar um futuro seguro para os seus.

Sem dúvida, é a partir de seu lugar como velha habitante que reflete, acerca do sentido das transformações urbanas, uma crise que "não existia antes": a violência na sua proximidade e banalidade, pertubadora de associações projetivas. É como idosa de uma condição de vida "média" que avalia a desfiguração de ordens temporais almejadas como contínuas. Entretanto, na condição de filhos de kronos que somos, o próprio envelhecimento lhe confronta à dialética temporal do viver como transformador da imagem de si frente à vulnerabilidade de novas rupturas na continuidade, até a própria morte. A experiência de envelhecer é também o processo de constituição da experiência temporal dos sujeitos, percurso de lembranças e esquecimentos, de linguagem e silêncios, de escolhas e desistências, mas que os requisitam ao olhar avaliador e ao gesto recriador, em cada palavra do trabalho da memória que é o trabalho de tomada de consciência".

A imagem da cidade evocada no presente é também o contexto que dilacera suas experiências de envelhecer e fragmenta seu reconhecimento como sujeitos da história da cidade que lhes aparece cada vez mais desencantada pela violência progressiva. Neutralizados como agentes de transformações, os velhos habitantes percebem-se ameaçados pelo esquecimento na cidade divulgada na mídia, que lhes sujeita à indulgência compreensiva na simplificação demagógica do estado de arte da criminalidade e da vitimização noticiados.

Sugere-se, entretanto, que a crise postulada é também uma crise de interpretação que permite, outras interpretações dos velhos habitantes que, ao folhearem a memória-contexto de suas vidas, ultrapassam o próprio conflito perturbador ao acomodarem os tempos de desordem em suas narrativas como movimentos incessantes de instauração de sentido, de "duração", ou na significação dada na dialética do ser na duração (Bachelard, 1989) dando aos ritmos temporais vividas, um encadeamento lógico e compreensivo. 
Em suas reminiscências, Dona Crista reordena o vivido embalado por mudanças conflitivas que vão sendo configuradas nos jogos da memória que reordenam as descontinuidades ritmadas por transformações espaço-temporais da "paisagem urbana" vivida cotidianamente.

Importa menos aqui a condição cronológica que condiciona os sujeitos nesta fase cíclica da vida, e mais a riqueza do testemunho que aportam a partir de suas histórias vividas, conforme Maurice Halbwachs (1968) elucidou (o teórico que diferenciou a memória coletiva da memória histórica a partir de um pertencimento afetivo à comunidade da lembrança), ao destacar nos velhos o privilégio de guardiões da memória por deterem de forma mais viva e presente que os demais adultos e crianças, as referências dos quadros sociais da memória.

É nos jogos da memória e do trabalho da imaginação criadora humana que podemos recolocar a experiência de envelhecer na vida temporal da cidade na dimensão de múltiplos significados, explodindo com o modelo linear da imagem do homem moderno configurado no processo de individualização que "coloniza",13 as etapas etárias e institucionaliza o curso de vida" ${ }^{14}$.

Neste sentido os velhos habitantes de Porto Alegre entrevistados se situam como narradores da memória coletiva da cidade, ou da consciência coletiva do viver a cidade, a partir de seus percursos individuais e familiares singulares. A partir de suas vozes cognitivas refletem sobre a fragmentação que o medo e a insegurança vão provocando nos seus mapas mentais afetivos nas territorialidades de pertencimento, na sua rua, no seu bairro, em suas redes sociais, ameaçando ao esquecimento as apropriações dramáticas que puderam realizar na vida urbana em seus rituais cotidianos.

Os velhos habitantes narram uma prolongada convivência em múltiplos ambientes da vida urbana local através dos quais vão relacionando dinamicamente o passado no presente, mapeando uma cidade de mudanças de condutas e atitudes, que comunica seus afetos territoriais, suas incertezas e evitações sócio-espaciais, as faces de medo e agonias, orientadas pela linguagem socializada e pelas emoções apreendidas, reconfigurando Porto Alegre como depositório de suas memórias-experiências sobre o que nos ensinou Walter Benjamin (1986, 1993 e 1995).

\section{Vozes na cidade}

Dona Eulália é moradora do centro de Porto Alegre há 54 anos. Vive em um apartamento amplo de classe média com o marido, Seu Mauro, aposentado do exército, e uma filha e uma neta.

\footnotetext{
${ }^{13}$ Mike Featherstone analisa a forma como especialistas da Psicologia do Desenvolvimento relacionam o curso da vida com fases cronológicas bem-demarcadas, tem-se o que chamamos de colonização das idades. (Featherstone in Debert, 1994:62).

${ }_{14}$ Guita Debert chama a atenção para o fato de que o processo de individualização, próprio da modernidade, teve na institucionalização do curso de vida uma de suas dimensões fundamentais. (Debert, 1994 : 8).
} 
Dona Eulália, hoje com 67 anos, veio morar ainda menina em Porto Alegre dada uma transferência de seu pai da cidade fronteiriça Uruguaiana, indo residir em rua próxima ao Palácio do Governo, território que mantém ainda hoje a função político-administrativa.

Segundo Dona Eulália “naquela época...ninguém trancava a porta”. Quase em tom de lamento explica que "havia uma plaquinha na porta com o nome do proprietário, todo mundo passava e respeitava" e antes de entrar as pessoas batiam na porta, batiam palmas ou chamavam pelo nome do proprietário.

Ao falar "desta época", situa que medos e temores ela só tinha da autoridade do pai, e é em valores morais que ela explicita seus cuidados cotidianos: "Não podia sair sozinha, nem eu, nem minha mãe, a gente só saía acompanhada, porque era assim mesmo. Perto do nosso bairro tinha uma zona mal falada", zona rotulada como de meretrício e que era evitada em suas trajetórias diárias.

Dona Eulália compara, por exemplo, os temores de sua época de adolescência:

Naquela época, olha, nunca se ouviu falar em assim assaltar e atacar, me lembro quando eu fui pro Instituto de Educação, eu já estava com 12 anos, de vez em quando aparecia no instituto um cara, como é que se chamava? Um exibicionista, e ficava se mostrando às vezes pras gurias, mas aquilo era a coisa assim mais chocante que acontecia. Tô te dizendo, a gente saía de casa as portas eram fechadas assim só com o trinco, e era aqueles trincozinhos que batia, deixava a janelinha pra abrir. Não entravam, não roubavam, todo mundo se conhecia, porque até a miséria era diferente, né? .. naquele tempo a diferença era de dinheiro mesmo, de gente pobre, mas eram todos pessoas assim, a gente brincava com os colegas pobres.

Hoje em dia a gente tem medo, se tranca toda. Acho que antes a gente não tinha medo de nada. Hoje, se a gente vai com uma criança pra praça a gente fica até com medo que roubem, né? Tem que estar sempre de olho.

É igualmente significativo nas narrativas, a identificação de um certo "momento", a partir do qual o sentimento de insegurança passa a ditar novas atitudes preventivas, como "chavear, trancar as portas", um indicador, dirá Roché (1993:135), da presença de medo pessoal ou preocupação por ordens comportamentais e verbais, individuais ou coletivas.

O sentimento de insegurança é experimentado nos pequenos gestos cotidianos de Dona Eulália e sinaliza a desintegração de valores que se materializaria nas situações de agressão. Para situar suas experiências e/ou sentimentos de insegurança de viver no mundo urbano, a interpretação é comparativa ao viver na cidade no passado como exercício de significar o presente. Crises de uma época não muito distante que conhecem novas feições:

Todo mundo morava em casas, aí começaram as dificuldades, começaram a roubar, a assaltar as casas... Então já começavam as pessoas a se fechar em apartamento. Ninguém 
roubava pobre. Já hoje em dia eles roubam até dos miseráveis, entram nas casas do miseráveis e levam tudo... Antes não tinha porque tu ter medo, se um guri mexia contigo e tu reclamava! Ah! já levantava dois, três homens para te defender. Hoje não, não tem ninguém olhando pela gente nem nada..

Desta forma, a breve harmonia da interpretação de situar uma superação de recalcamentos passados que podem ser extensivos aos conflitos interiores vividos num passado recente (o medo à autoridade, a vergonha do olhar moral do outro), é encompassada por uma outra ordem de embaraços (não necessariamente intimista), que acompanha o sentimento de que, para manter sua posição na rede humana, deve-se deixar novamente "fenecer sua verdadeira natureza" (Elias, 1994: 33).

Dona Eulália sugere uma transformação importante frente ao impacto da violência e do temor sobre o cotidiano das pessoas que passaram a recorrer aos apartamentos para maior segurança, ampliando as razões práticas destes símbolos de urbanização e massificação populacional das cidades verticais, idealizados por Le Corbusier como condição da galgar a liberdade individual (Jacobs, 2000: 20). Enfoque reforçado pelo relato de Seu Mauro. Aos 73 anos e vivendo em Porto Alegre desde 1928, morava com sua família (pai militar) no Grande Hotel e no Hotel Majestic antes de mudar-se por um período mais longo para a José Bonifácio ${ }^{15}$. Também militar, exerceu atividades em várias cidades brasileiras, retornando em sua aposentadoria a residir no centro de Porto Alegre em apartamento em edifício situado na rua considerada o centro da cidade, a rua dos Andradas, cognominada de Rua da Praia. Justifica que sua opção foi "para maior comodidade $e$ segurança".

Seu Mauro busca temporalizar um aumento do sentimento de sua vulnerabilidade à vitimização ao justificar seu receio em percorrer certos lugares pela presença da violência, contrastando com seus hábitos de passeios no centro da cidade no passado. Nas décadas de 50 e 60 , o footing na Rua da Praia era hábito recorrente de um grupo emergente no processo de modernização da cidade: a classe média.

O adensamento da cidade e o fenômeno urbano que se complexifica (divisão social do trabalho, distinções sociais, êxodo, desemprego) são causas, para Seu Mauro, de um estranhamento à concentração popular. A imagem do “outro” na Rua da Praia no passado contrastada ao presente:

Da década de 70 para cá. Bom, até 60 ainda se tinha a Rua da Praia ainda se conservava um pouco, vamos dizer uns $70 \%, 60 \%$, do que era antes.

(Narra longamente passeios com seus pais, o clima familiar dos passeios, os footings, os cafés

\footnotetext{
15 Rua circundada pelo maior parque da cidade (Parque Redenção), pelo Colégio Militar e por edifícios residenciais.
} 
da época, chocolaterias, etc. Época em que Porto Alegre contava com 275 mil habitantes e conhecem uma importante urbanização das zonas centrais e o surgimento de vilas irregulares na periferia.).

A quantidade maior era bem-arrumado. O pessoal de fora vinha menos ao Centro. Mas a gente já começava a notar a diferença, porque uns eram dum jeito e outros eram de outro. $O$ pessoal dessas vilas populares aparecia por aí, se sentia a diferença.

Hoje o pessoal de fora vem mais ao Centro, essas vilas populares aí, vêm mais. É o perigo hoje. De assalto, de roubo. O pessoal... O desemprego tá começando a crescer, a porcentagem de desempregados. E o pessoal desempregado, com filho, com isso, com aquilo... termina fazendo qualquer negócio.

Hoje aqui na frente, a tardinha principalmente seguidamente a gente escuta pega ladrão, pega ladrão... seguidamente essa Rua da Praia aqui toda. Aqui no centro assaltam muito, roubam muito. É mais gurizada assim, 18, 19, 20 e poucos anos que roubam e um passa para o outro e tal. Depois ninguém sabem quem foi ou não foi. A polícia às vezes anda, ontem mesmo eu vi a Brigada, pegou meia dúzia ali, encostou na parede e tava revistando...

A prudência passou a ser uma regra do cotidiano. À luz do dia arriscam o convívio em lugares públicos, já ao escurecer evitam sair, e a entrada de qualquer desconhecido é controlada por um serviço de portaria com vigilância as 24 horas, que comunica por interfone interno a presença de um visitante. Uma série de práticas é desempenhada para modular o cotidiano da neta, num quadro de forte segurança: “Eu levo e busco de carro" sentencia a avó.

As estratégias para preservar um estado de segurança é indicativo, pois, de um ato considerado cada vez mais civilizatório nas cidades: não é apenas a rua que é evitada como local favorável aos crimes contra a pessoa, mas a própria "casa" precisa ser fortalecida e assegurada às ameaças do mundo criminal. Para proteger o mundo doméstico, a vida privada, apela-se a instrumentos protetores materiais (alarmes contra roubo, etc) e cursos de defesa pessoal, investe-se em protetores cotidianos (guardas, etc) contra o vandalismo, roubos e assaltos. A paisagem urbana de Porto Alegre conhece, assim, de forma acelerada uma vitalização das estratégias de segurança que vão figurando uma cidade a partir de uma estética do medo.

Para seu Mauro, o temor que sente na rua é motivo para um certo reclusamento seu e da família no âmbito do apartamento. Hoje a cidade é o grande contexto público que prima pela insegurança e desordem. Ao referir a hegemonia de condomínios fechados para classe média, acrescenta:

Ah, hoje o individualismo tomou conta da população. Cada um primeiro eu, depois eu, depois eu, depois eu, depois a minha mãe... e olhe lá. E olhe lá... Não, hoje a coisa tá desse jeito. Por incrível que pareça... é verdade. 
Seu Mauro aponta para uma importante conseqüência do enclausuramento forçado em que são obrigados a viver nestes tempos atuais: o enfraquecimento das relações de vizinhança que implicam num decréscimo das relações de amizade e solidariedade. Mas relativiza seu pessimismo e seu temor apontando para sua participação em redes de sociabilidade ao situar seu pertencimento ao grupo de aposentados no clube Militar com encontros periódicos onde se sente "entre amigos" e "grupo de terceira idade" da paróquia católica local.

A critica ao individualismo exacerbado beirando um narcisismo como metáfora da condição social de nossos dias (para citar Lasch, 1983) traz, interpenetrado ao tema da crise, a noção do enfraquecimento dos sentidos de socialização pela privatização, em certas esferas da vida (vizinhança, comunidade, família), das relações tradicionais (hierarquia, solidariedade, reciprocidade). A trama do tempo é a fragmentação dos laços e valores de reciprocidade. A personalidade individualista, diria Sennet, desintegra as relações, fragmenta os sentidos, impondo aos sujeitos uma ideologia da intimidade (Sennet, 1979).

Esta idealização da vida pública no passado (presente mais em Sennet que em Lasch (1983: 52-53) é um exercício reflexivo significativo nas ordenações temporais dos entrevistados, como revela a narrativa do Seu Ronaldo:

Eu sempre morei nesta rua. Tá, eu nasci em Passo Fundo e vim pra Porto Alegre com 15 anos (tem hoje 71 anos e sua esposa não informou a idade). Eu trabalhava no centro mesmo (relato sobre a profissão). Naquela época quase não tinha edifícios...Eu tinha um fusquinha que dormia na rua. Eu chegava de viagem e deixava o carro na rua, não tinha problema nenhum e os meus filhos brincavam no meio da rua, só se cuidava o bonde... Era muito tranqüilo... só era perigoso andar de noite no Alto do Bronze, perto do presídio... era uma parte mais pobre, mas aqui em cima era ponto nobre. Eu cansei de sair assim, domingo a noite, eu também trabalhava à noite, a gente saía, jantava e ia passear no centro, olhar vitrine, era um baita programa. Lá pelas 8 da noite eu e minha mulher íamos passear, voltava pra casa às 10 horas sem pensar em assalto nem nada, agora está um terror. Eu andava a pé até duas da manhã e tudo bem, eu tinha dois empregos e nesse da noite eu voltava pra casa a pé... Olha, eu digo que está perigoso, nunca fui assaltado, só roubado, numa sexta-feira à tardinha alí naquela praça em frente à Santa Casa. Então eu acho Porto Alegre muito perigosa e violenta. Já pensei em me mudar para a praia. Tá todo mundo fazendo isto..." (continua a narrar os motivos pelos quais ainda não consolidou este projeto).

Seu Ronaldo e Dona Joyce, moradores da rua Duque de Caxias no centro da cidade, explicam que todo o edifício é gradeado, mesmo tendo serviço de portaria; mais recentemente o condomínio contratou o serviço permanente de segurança de rua, facilmente identificável nas guaritas que proliferam nas ruas da cidade.

A estética do medo é a constatação material mais figurativa na transformação da cidade, 
impulsionando seus habitantes, sobretudo os aposentados, a buscarem maior segurança. Justamente são os segmentos médios, com um certo poder aquisitivo, que irão recorrer ao gradeamento de suas casas, edifícios e janelas e à instalação de alarmes em suas casas e carros. Os edifícios têm porteiros eletrônicos e as ruas se povoam de exércitos pessoais para vigilância. Seus hábitos e rotinas são igualmente estilizados pela estética do medo. Conforme Seu Ronaldo:

Seu Ronaldo:

De uns 10 anos pra cá... De noite eu não saio mais, só às vezes, na casa de um filho, mas aí agente chega em casa e ilumina bem a entrada do edifício pra ver se não tem nenhum ladrão esperando pra assaltar, e já entraram no nosso apartamento antes. A gente morou um tempo na Nilo, é um daqueles edifícios pequenos ali da rua, tem só quatro andares, tem zelador mas não tem portaria permanente, aí num dia de manhã o cara conseguiu entrar, foi no andar de cima, a moça, empregada, abriu a porta e ele entrou, ele estava armado, aí chegou a filha da dona de camisola e ele mandou ela se vestir, era um negrão, né? Ele levou jóias e levou o dinheiro que tinha em casa. No dia seguinte nós fomos pro parque de exposições de Esteio, quando voltamos pra casa eu botei a chave na porta, e abri com o trinco, virei pra minha mulher e disse pra ela que ela tinha se esquecido de trancar a porta, e ela respondeu que nem bêbada iria esquecer, nós notamos que o freezer estava desencostado da parede, e ali era uma entrada de ar e ele entrou por ali. Por sorte a minha mulher tinha fechado à chave a porta que leva pros quartos e o cara não conseguiu abrir, ele só levou um anel que tinha caído no chão e amassou...eu tinha deixado em cima da geladeira pra lembrar de levar na relojoaria pra consertar. Depois os caras botaram guarda e grade em tudo, então a cidade assim, nesse edifício aqui em 30 anos houve um roubo só. Foi quando o zelador foi pra um Gre-nal e deixou o edifício, foi embora, entraram e roubaram. O fato de ter um porteiro 24 horas não evita o roubo, mas dificulta."

Dona Joyce: "O nosso prédio lá da Nilo não tinha porteiro 24 horas, então botamos porta de ferro. Essa porta de ferro aqui foi idéia do vizinho. O ladrão te espera quando tu chega em casa, quando tu encosta o carro ele quer entrar junto na garagem, quando tu vai abrir a porta do edifício a pé ele está te esperando pra entrar dentro."

Seu Ronaldo resenha um temor muito presente, o atentado ao patrimônio por latrocínio, roubo ou furto. Nas famílias de classe média, cultivadoras de uma vida privada marcada pelo conforto material e objetos portadores dos sentimentos burgueses, o ataque ao patrimônio é temor constante. Dona Joyce identifica as seqüelas da explosão do crime organizado em Porto Alegre, que configura a década de 80, e a disseminação do crime pelos bairros, que se acelera na década de 90 e que deixa a população em pânico frente a criminosos e/ou quadrilhas cada vez mais armadas em práticas audaciosas como assalto a carros e edifícios que, embora seguros, têm no seqüestro de algum morador ou funcionário ameaçados à morte e lesões corporais, a garantia do sucesso da transgressão.

Outro entrevistado, Seu Jorge, poeta, é apaixonado por sua cidade, por seu bairro. Funcionário aposentado, aos 70 anos em 1997, é proprietário de um apartamento simples em bairro residencial nas proximidades de uma das principais artérias comerciais e de lazer da cidade de Porto Alegre, a 
Avenida Osvaldo Aranha. Residem com ele, além de sua esposa, um filho e um neto (tiveram 5 filhos e 5 netos).

Relata longamente seus hábitos um tanto boêmios no centro da cidade, com destaque para a freqüência ao Restaurante Maria, próximo ao mercado público, ponto de encontro de poetas amadores. É elaborando um jogo contrastivo com as recordações de um "passado seguro" com "espírito comunitário" que seu Jorge sentencia ser "a segurança, o maior problema na atualidade, nesta cidade”, desabafo acompanhado por sua esposa: "o maior problema".

É justamente sua esposa (Dona Pérola, 59 anos em 1997) que situa a presença do valor medo na socialização do seu neto:

Eu tinha pena de assustar, mas aí entraram aqui em casa (relato do arrombamento)... agora eu não tenho mais pena de assustar, tem que avisar. Meus meninos quando eram pequenos eu tinha pena de assustar, porque eu acho que a pessoa viver assustada, né, é horrível. Os meus tipos de susto eram outros naquela época: minha mãe dizia, 'não come isso ouviu! isso faz mal'... minha mãe dizia que manga com água não podia, me metia medo assim né, que hoje não existe mais, hoje é o medo dessa violência.

Seu Jorge assinala terem aderido ao signo mais presente dos traços de hostilidade e desconfiança em relação ao “outro” e requisito básico de proteção, a grade de ferro:

Nós gradeamos tudo aqui agora, já fazia algum tempo que nós pensávamos em colocá-las com medo dos assaltos.. aqui na frente é ... nossa! Não existe mais segurança.

Dona Pérola acrescenta:

"Uma vez assaltaram nossa filha dentro do carro, saindo de dentro do carro, ela e o namorado".

Então vê o perigo que tá essa zona aqui hoje? De uns 10 anos para cá... esta rua é meio caminho de tráfico... essa mudança dessa atualidade né, as drogas modificou completamente ..." (segue falando da beleza do parque Farroupilha próximo a sua casa, que descreve criticamente como território perigoso dada a circulação de drogas, homossexualismo e prostituição)

Socializar seu neto com a ameaça iminente da violência urbana retira do fenômeno da violência sua anormalidade para situá-la como estruturante da sociedade. Seu depoimento associa um sentimento de perda de ideais sociais que se fragmentam na poeira do tempo com o crescimento da violência urbana.

Como eu disse ainda há pouco, sabes que até algum tempo atrás, existia um pouco de espírito comunitário. Hoje em dia não existe mais esse espirito comunitário, nós procuramos defender a nossa família. Então a gente procura dar alguma coisa para a comunidade com o exemplo que a gente dá aos filhos, os ensinamentos para que ele não venha a perturbar o outro porque eu, sinceramente, na situação que estamos vivendo hoje nesse país politicamente .... Então eu procuro me doar à minha família. Isso não quer dizer que um vizinho vai cair no chão, numa casca de banana, e eu vou passar, e não fazer nada, não vou menosprezar o vizinho, mas eu não tenho mais condições de freqüentar os outros, conversar assim, vamos melhorar isso (desvia para questões do condomínio), colocar uma lâmpada aqui. Não! eu tenho que ficar dentro de casa, infelizmente, 
egoisticamente eu falo. E lamentavelmente todo mundo está fazendo a mesma coisa hoje.

A frustração com que se qualifica as relações hoje mais presenteístas mescla os embaraços das experiências subjetivas no mundo moderno, as feições do medo e as estratégias sociais "necessárias" para evitar oportunidades de agressão. Mas na preocupação com a segurança, o maior temor é à vitimização pessoal. A experiência de modo geral é lembrada em detalhes que pressupõem, eventualmente, o difícil esquecimento. O casal Zelia e Jonathan, já haviam passado pela ameaça de vitimização, como pontuam seus relatos.

Acostumados com as mudanças geográficas exigidas pela profissão bancária, a escolha de morar em edifício em bairro residencial foi opção para o enraizamento após a aposentadoria. $\mathrm{O}$ bairro Cidade Baixa, evitado no início do século pela sua identificação com comunidades de descendência africana, mais tarde transferidas para a periferia, passou a abrigar edifícios residenciais para segmentos médios e uma importante vida noturna (bares e restaurantes). Mesmo assim possui ainda hoje alguns raros pontos de barracos concentrados, denominados "ilhas" de favelas. Esta é pelo menos uma das razões que Zélia sugere para explicar os freqüentes assaltos na parada de ônibus ou no interior do ônibus, experiência da qual foi uma das protagonistas. O inesperado da situação, explica Zélia, a deixou por vários dias amedrontada. A relação sem conteúdo lhe aparece disformada - "levei tempo para passar o susto" - e sua preocupação se deposita no horário tardio do retorno de uma filha ainda estudante:

Minha preocupação é com Lúcia, mas agora o noivo tá indo buscá-la e eu fico mais tranqüila do que se ela tivesse ainda que voltar sozinha.

Seu Jonathan traz em seu relato de atentado uma performance pouco estimulada pelas regras comportamentais sugeridas pela polícia e divulgadas pela mídia para evitar a fatalidade maior: "a reação frente a criminosos impacientes e nervosos e muitas vezes drogados". A intemperança aqui situa-o no interior de um habitus masculino, apelando para uma violência lícita pela honra, como podemos interpretar na sua leitura da experiência. A coragem e a valentia constituiriam as ordens de significações possíveis ao imprevisível e ilícito.

Olha, eu fui assaltado várias vezes. Tentaram me assaltar várias vezes mas nunca me levaram nada. A primeira vez foi aqui bem perto né... Tinha entrado numa padaria pra comprar pão, e eu carregava o dinheiro no bolso esquerdo sempre, porque eu sou canhoto. E o sujeito meteu a mão no meu bolso direito. Não foi propriamente assalto. Ele tentou me levar alguma coisa do bolso, né... Mas só tinha papel com uns endereços aqui no bolso. Tirou, saiu correndo... Eu vinha com uma máquina de moer carne na mão, soltei a máquina e tentei sair atrás dele, mas o cara era rápido que era uma coisa braba. Disparou. E eu não pude nem... notar quem era. Eu sei que era... o sujeito assim era um... mulato, moreno. Puxando prá preto. O cabelo levantado assim. Um rapaz novo. Porque se locomoveu muito rápido. Eu saí atrás dele e já ia a uns 20 metros, 30. 
A segunda vez também foi aqui perto. ... E a outra vez, ...

A outra vez, não sei se foi antes, ou depois...

E no mesmo lugar que tinham me tirado o talão de cheque, dessa vez...

Uma vez um garoto ...

E agora, não faz muito tempo, eu tava, era um domingo, eu ia atravessando ali, naquele... próximo àquele largo Glênio Peres, por ali. Eu ia me aproximando em direção à Praça $X V$, ali, era um domingo de tarde, tava cheio de gente ali, né. Mas tudo desocupado assim, marginais, que ali... freqüentam muito naquela região ali, né. $E$ não havia quase policiamento. E o sujeito me meteu a mão nesse bolso aqui, prá pegar dinheiro, e eu segurei a mão dele também, segurei a mão e apertei e ele tirou a mão, com dificuldade até e se escondeu atrás duma árvore ali. E eu fui atrás dele, fui atrás dele e um dos caras que viram ali me aconselharam: melhor não ir lá, melhor chamar a polícia, melhor não ir lá que esse cara vai reagir. Se escondeu atrás duma árvore grossa.. Aí eu deixei, não fui chamar nem polícia... ele não levou nada, também. Só fui quando roubaram o talão de cheque. Mas depois que eu saí, eu fui ver, o meu bolso tava todo danificado.

Eu se eu puder pegar o sujeito eu vou estrangular o cara, né. Ou ele me mata, ou eu mato ele. Uma das duas. A minha reação é pegar o sujeito e bater, bater no cara. mesmo que seja de mão aberta assim.... geralmente esses caras andam caindo de magro aí, de pobre, de doente também. Eu se puder segurar o sujeito, eu seguro. Se eu levar a pior, aí azar meu. Eu não me abaixo prá esse tipo de gente, eu não me abaixo. A minha reação é de reagir. Ele nota se a gente fica com medo. Ele nota porque ele tem muita prática disso. E se tu ficar com medo dele e te encolher, eles vêm mesmo pra cima. E se a gente ameaçar e sair atrás dele, eles já sabem que o cara não é assustado, né.

Mas tanta autonomia não se mantém no discorrer do seu relato. Rende-se à sensação de vulnerabilidade frente ao imprevisível e "toma precauções": A mudança nestes pequenos hábitos vai dando os contornos da estética do medo:

\footnotetext{
Se nós vamos passear de noite, a gente pega táxi. Chama o táxi aqui na frente. E se é de dia, não levo algum objeto que eles possam me levar assim, como relógio, ou aliança, eu não levo.

De uns 4 anos prá cá a gente colocou grade na frente do edifício..De noite a gente não atende, porque quando é alguma pessoa que quer alguma coisa com a gente, geralmente a pessoa liga antes né. ... eu não sei se tu viste, mas tem grade até na porta. Porque esse edifício aqui, antes de nós virmos prá cá, ele já tinha sido... por duas vezes entraram nos apartamentos. Então a síndica mandou colocar essas grades de ferro por isso sabe? Pessoas que trabalham, saem de manhãa, só voltam à tarde, chegaram em casa e encontraram o apartamento totalmente depenado, levaram tudo.
}

Interessante destacar na narrativa do seu Jonathan o tema do gênero, tão importante nos estudos antropológicos sobre envelhecimento, e as diferenças constatadas nas experiências masculinas e femininas. Percebe-se aqui que se ao homem é dado maior valor na experiência de envelhecimento por sua situação de rompimento com a vida ativa/aposentadoria, uma vez que as experiência da mulher é de restrição ao mundo doméstico (Lins de Barros, 1998), é justamente os homens que, de forma mais acentuada, conhecerão os determinantes desta nova condição de insegurança e temor à vitimização. Acostumados que estavam ao aproveitamento do tempo livre da aposentadoria para o convívio em formas de sociabilidade masculina no mundo público (rua), a opção pela restrição maior ao mundo doméstico, torna-se freqüente. 
Há de qualquer forma uma desconstrução de ordem apreendida e o esforço de construção de enfrentamentos às circunstâncias, táticas cotidianas de resistência, diria De Certeau (1994), na busca de sentido numa história de mudanças contingentes.

Conheci Dona Nora através de uma amiga que havia me comentado que ela estaria para se mudar de sua casa familiar há 30 anos para um apartamento. Abalada com o falecimento do seu marido, comentou sobre a decisão de sair da casa:

Não é que tenha medo de ficar sozinha, mas eu não gosto de ficar sozinha, não compreendo, tenho amigas que dizem que adoram ficar sozinha, não precisam de ninguém, eи sou uта pessoa completamente dependente de alguém ... adoro esta casa, mas também estou envelhecendo e ficar sozinha neste casarão... é perigoso. Então, para mim, o apartamento fica mais fácil, apesar que vou sentir uma falta enorme da minha casa, eu amo ela, aqui criei os meus filhos e passaram os anos mais importantes da minha vida. Mas tudo muda, no apartamento tenho porteiro 24 horas. E aqui teria que ter alguém para vigiar e aumenta as despesas. No edifício, tem zelador, porteiro 24 horas, porteiro eletrônico, facilita muito a vida e tem mais segurança.

Dona Nora situa neste relato a problemática da relação do idoso com sua família, característica nos segmentos médios, somada às estratégias e táticas a serem apreendidas pelos idosos que optam por residir em suas próprias casas. Explica que nenhum filho quis permanecer na residência da família após a idade adulta; o casamento e a independência econômica permitiram a construção de novos projetos familiares. Justifica ela que esse era um hábito do passado e hoje a época é outra. Destaca então a sapiência do seu marido, que repetia "viver não é difícil, o difícil é conviver". E acrescenta:

Essa gente moça hoje fala muito em seu próprio espaço, fala-se muito no espaço, os velhos nunca tiveram espaço, mas agora os velhos estão querendo seu espaço, porque é o espaço de ter realmente o seu silêncio, quando se quer silêncio, de se deitar a hora que quiser, de sair, viajar, um direito que a gente tem na velhice e que se morar com outro não se tem esse direito.

Nora critica filhos que jogam seus idosos em asilos, mas também não quis "a saída" da casa geriátrica, "pelo menos enquanto eu puder ter autonomia, né!” Uma vez que nos restringimos a entrevistar pessoas residentes em seus próprios lares, entre os entrevistados o recurso do asilo ou da casa geriátrica é bastante estigmatizado. Dona Nora expõe uma série de estratégias tomadas para poder conviver sozinha, com autonomia, "sem atrapalhar" os filhos, mantendo os vínculos familiares e trocas de favor, como a tarefa de cuidar dos netos, situação que desempenhava na hora mesmo da entrevista. Explica que quando sai por um tempo indeterminado, telefona para os filhos e avisa sobre seu deslocamento e itinerário. Justifica que estes cuidados são importantes, pois desde quando seu marido vivia, sempre ligava avisando do seu retorno para ser aguardada: 
Dava uma buzinada, ele abria o portão e já entrava. Agora tenho esta menina que é empregada do meu filho, está dormindo aqui provisoriamente. Mas normalmente a esta hora (20 horas) eu já cheguei. Para não arriscar, sabe .... Agora hoje minha filha passa aqui, me liga, eu ligo, a gente tá sempre se vendo.

Desta forma Nora exterioriza um temor de alguma forma presente nas narrativas: poder manter na velhice uma qualidade de vida independente e autônoma, pelo menos enquanto a doença e a perda da consciência de si mesma não lhe imponham a morte social. ${ }^{16}$

Dona Raquel, de 60 anos, profissional aposentada, divorciada, que mora em edifício de segmento médio em bairro central, tem uma experiência significativa neste sentido. Se auto-avalia como tendo sido "uma mulher decidida". Foi a única mulher de uma família de imigrantes do interior gaúcho de predomínio étnico italiano, a enfrentar uma vida de estudos na capital. Na época (1953) recusou uma arma que seu pai insistia que ela usasse para autodefesa. No interior, explica, era comum ter-se uma arma em casa; já em Porto Alegre, explicou não achar necessário:

Eu não tinha medo... meus pais nunca inculcaram na gente o medo, eu não temia as coisas. Eu sempre fui valente, mais arrojada... Não que as pessoas não tivessem medo, umas amigas que moravam do outro lado do parque Farroupilha atravessam correndo porque tinham medo. Mas eu não me lembro de coisas temerosas desta época. Eu trabalhava na periferia e tudo como diretora, diziam que era um lugar de delinqüência, não tinha policiamento, mas não era perigoso.. enfim, como eu era mais jovem (eu e meu marido então) não tínhamos medo. Não tinha esse problema de temer ser assaltada na rua. Até uns anos atrás, não lembro de nunca ter medo de andar na rua.

Raquel casou-se e teve três filhos (uma menina e dois meninos, hoje tem um neto). Uma situação de vitimização vivida por seu filho, segundo ela, foi o início de alguns acontecimentos desagregadores de sua história familiar. Seu filho fora perseguido e assaltado por um "grupo de delinqüentes" a gangue da Matriz, como foi denominado um grupo de jovens assaltantes que atacavam na região da Praça Matriz, no centro da cidade, que chegou a ser noticiário dos meios de comunicação: "Ele ficou muito fragilizado", explica, e foi o início de uma história de depressão que o levou à morte.

Seu relato segue situando uma segunda ruptura drástica de uma rotina familiar, a perseguição política, a prisão sua e do marido. Esta experiência de trauma somada a problemas de saúde levaram-na a prática da yoga como uma "busca de equilíbrio":

\footnotetext{
${ }^{16}$ Aspecto analisado por Myriam Moraes Lins de Barros em seu artigo "Testemunho de vida: um estudo antropológico de mulheres na velhice", constatando que a perda de consciência e a velhice-doença era o maior temor pela ruptura do projeto de viver a velhice. 1998:165.
} 
Eu buscava um caminho... tentei o espiritismo e não gostei, não sabia o que queria, queria uma filosofia de vida, e aí uma amiga minha me falou do grupo esotérico.... Eu agora faço parte, nós estudamos textos de filosofia de vida buscando um caminho... era tudo que eu queria na vida, um grupo para estudar juntos (grupo denomidado Tempo Astral ou Grupo Universal, também denominado simplesmente de Grupo Esotérico).

O fortalecimento do sentido religioso (bastante presente em várias narrativas) é tema complexo para tratar com profundidade neste contexto. Desde o catolicismo tradicional até a terapia se fazem presentes. Neste caso específico, a afirmação de um crescimento individual, busca um rearranjo da vida interior mediada pelos "saberes psis" (Salem, 1992: 69) ${ }^{17}$ que contrasta com uma grande maioria de idosos católicos entrevistados, que se mantêm em redes de sociabilidade católica e em projetos pessoais de devoção à tradição judaico cristã do amor como auto-sacrifício e ideal de salvação.

Na sua narrativa, Raquel diz que esta opção espiritual de vida lhe ajudou em vários aspectos, "eu por exemplo, tinha uma arma em casa". Mas passou a superar o medo e desvencilhou-se da arma. Porém, foi sobretudo para superar um segundo afastamento (menos drástico) que re-situa a importância do grupo esotérico, o reencontro com a solidão quando seu último filho resolveu sair de casa:

"Sabe o que é você chegar em casa e ninguém estar te esperando? Ninguém mexeu nas tuas coisas, ninguém te esperando, não ter ninguém para conversar em casa, para dividir, alguém que vai chegar e vai fazer um barulho na porta?’.

O medo da solidão revela um traço importante da vida contemporânea, que pode ser esboçada por uma cultura privatista, uma vez que se tornou "um fenômeno endêmico" da vida caracteristicamente urbana. À solidão pública das massas se acrescenta uma dose ampliada de temor à vitimização, encurralando o cidadão nos domínios do privatismo "não só pela hibernação emocional do homem moderno" (Carvalho: 1995: 193), mas pelo temor da busca de espaços de interações em lugares públicos. No caso das pessoas idosas, este parece ser um dos maiores dilemas, sobretudo nos segmentos médios, onde o idoso tende a permanecer vivendo só após a partida dos filhos ou após a perda do cônjuge.

A visibilidade desta condição solitária é um dos pontos de maior motivação para os programas para a terceira idade angariarem novos adeptos. Também as formas associativas tradicionais, como grupos religiosos, associações e programas para a terceira idade que, segundo Debert, "são formas de associativismo em que a idade cronológica é um elemento fundamental na aglutinação dos

17 “Os saberes 'psis' afirmam-se como importante foco de produção social de representações sobre o indivíduo moderno". (Salem, 1992: 69). 
participantes" (Debert 1999:138), mobilizam uma importante população (sobretudo mulheres) em geral promovendo uma sociabilidade lúdica e de re-investimento de laços afetivos de amizade e convívio social.

O recorte dado à história de Raquel sobre viver na cidade a partir das feições do medo e inseguranças paradoxalmente é também captar seu esforço de duração (durée) social na luta contra a desordem e a desagregação social, posto que "não existe nenhuma razão, natural ou não, para que uma sociedade se conserve, salvo justamente a sua cultura, que é o instrumento de luta contra a dissolução" (Duvignaud, 1983: IV). Tal como na mitologia grega, o medo personificado por Fobos e por seu irmão Deimos, o pavor $^{18}$, têm uma irmã chamada Harmonia, que vislumbra o restabelecimento da ordem e da segurança. A interação de Raquel em rede de cultivo espiritual, assim como em outros exemplos citados pelos entrevistados, promove este exercício de reencantamento da vida.

\section{Insegurança e cultura do medo}

Os relatos de como vivem e pensam os velhos habitantes no contexto urbano marcado pela imagem da violência, permitem refletir sobre as experiências de envelhecer neste contexto próximo à obsessão pela segurança e a generalização do sentimento de medo a todos os lugares no social.

Em um estudo dedicado à sociedade francesa, Giles-Sims (1984), ao analisar a preocupação com a vitimização criminal entre pessoas da terceira idade, observou que o aumento desta dependia da percepção que as pessoas tinham de sua possível vitimização. Isto é, quanto mais uma pessoa acredita em sua provável vitimização, maior a possibilidade de ela ficar preocupada com o assunto. Corroborando estes dados, Beristain (1992) refere a vitimização subjetiva - as vítimas do temor. Para ele, este temor pode ser produzido desde uma realidade objetiva até um menor ou maior grau de subjetividade (Rovinski, 1993:52). Impactos do viver urbano que podemos já encontrar nas reflexões de Georg Simmel em 1902 sobre o psiquismo do citadino, ao inferir à cidade moderna, o lugar da atitude blasé (Simmel in Grafmeyer et Joseph, 1984: 61 a 77).

Mas não se trata de conferir ao medo e à insegurança apenas o estatuto de mais um estímulo ao psiquismo a que são submetidos os indivíduos nas grandes metrópoles e "fazem dele um ser com elevada consciência de sua subjetividade e lhe confere, ao mesmo tempo, uma atitude de autopreservação frente aos estímulos recebidos" (Lins de Barros, 1987:17). Toma-se as feições dos medos como estratégias para tematizar os exercícios de re-ordenação do tempo vivido no contexto

\footnotetext{
${ }^{18}$ Ambos são filhos de Ares, o Deus da Guerra, e acompanham seu pai por onde houver conflito e sangue.
} 
urbano através dos jogos da memória dos entrevistados, sem perder de vista que "o medo é um fato social que varia segundo os lugares e as situações" (Roché, 1993: 41). A cultura do medo vivida pelos grupos urbanos em questão, desestabiliza a previsibilidade da cosmovisão de grupos e de suas ações rotineiras a partir de referências institucionais e papéis socialmente objetivados. Há uma ruptura para os habitantes da liberdade de acessar as diversas redes que consolidam seu universo cognitivo e contextualizam seus atos de socialização e que integram suas biografias.

O medo da violência dilacera as previsibilidades que giram em torno das experiências de vida para dinamizar as ações presenteístas e coloca em xeque as projeções de trajetórias na vida urbana. Previsibilidades ancoradas em um capital cultural e mapa simbólico tão importantes na "autointerpretação coletiva que representa a concepção comum, interna, da comunidade" (Schutz in Wagner 1979:19), ameaçadas pela perda de orientação de suas antigas noções relativas à conduta diária. O medo da violência urbana se coloca assim como tendo uma relevância imposta aos citadinos pela força com que participa do cenário cognitivo do mundo da vida, contendo portanto uma "relevância temática", nos termos de Schutz (in Wagner 1979:23), onde os indivíduos frente uma situação problemática, tem de se preocupar em reconhecer o problema, e a partir destas atividades cognitivas e "interpretacionais" desenvolver estratégias para resolvê-lo. Desta forma o medo da violência urbana, passa a fazer parte da herança social da comunidade cultural a ser transmitida à gerações mais novas.

O sentimento de insegurança pela imprevisibilidade se coloca como um problema com relevância que obriga os sujeitos a traçar novos procedimentos no mundo da vida cotidiana, inserindo os projetos de agir, numa dramática cotidiana, especialmente entre os idosos, vítimas em potencial nos espaços públicos dos "descuidistas", dos "trombadinhas", para citar algumas formas de agressão de roubo e assalto, imagem bastante recorrente na mídia jornalística. Os idosos, portanto, aparecem como uma população bastante propensa a desenvolverem um sentimento de receio e ressentimento face ao desamparo e impotência de ação.

Seguindo a teoria das tipificações de Schutz neste ínterim, pode-se sugerir que o medo "define a situação"19 e conglomera o "duplo caráter da motivação: "os motivos a fím de", essencialmente subjetivos (que prescreve as tentativas idiossincráticas do indivíduo de se orientar) e "os motivos por que", que indica "as razões dos homens para as suas ações enraizadas em experiências passadas" (Schutz in Wagner, 1979:27).

Desta forma, é um elemento perturbador, não só da concretização de projetos de vida, mas da

\footnotetext{
${ }^{19}$ Concepção de William I. Thomas, conforme Schutz in Wagner, 1979:26.
} 
própria elaboração de novos projetos pessoais dada a incorporação do medo como emoção preponderante na "experiência da dúvida" (Schutz in Wagner, 1979), uma vez que são as emoções a base do processo da construção de projetos pessoais-sociais ${ }^{20}$.

É o exercício de idealizar ações e planejar o futuro, característico das dinâmicas de estilo de vida de segmentos médios urbanos ${ }^{21}$ que os citadinos percebem ameaçados de ruptura motivados pelo sentimento de medo, insegurança e pânico associado ao risco do livre ser nas esferas públicas e mesmo privadas de sua existência.

Mas importa complexificar a noção de cultura do medo para além das condutas conscientes de mudanças de projetos e ações motivadas pela insegurança num campo de possibilidades de vitimização, posto que o método hermenêutico nos permite decifrar os comportamentos simbólicos do homem, "o trabalho da tomada de consciência" (Ricoeur 1988:4), que nos aproxima do propósito de elucidar sobre "a dinâmica entre memória individual e coletiva"22 que situa as feições do medo nas múltiplas formas dos velhos habitantes interpretarem suas trajetórias vividas, construindo a partir desta "referência" - o valor medo - a imagem que compartilham do viver na cidade.

Trata-se aqui de se conceituar o medo como valor ${ }^{23}$. Toma-se a noção de medo como contendo qualidades simbólicas, como um "valor" que funda a oposição hierárquica, segundo Louis Dumont, em nome do qual se realiza o processo de englobamento das idéias relacionais que amalgama a idéia de cultura como sistema simbólico e de sociedade como atualização de uma nova ordem social. Neste, a apreensão e a interpretação que os sujeitos fazem da realidade vivida é a abstração ou a classificação de uma ordem simbólica do mundo, mas também construção de uma inserção social onde se deve deter os diferentes níveis de interação cultural no seio da sociedade dominante. Isso implica dizer que esta inserção encontra-se colada a "situações" ${ }^{24}$ que combinam os valores e dão sentido às práticas sociais, imprimindo lógica e sentido à vida.

Dimensiona-se, assim, a partir de uma situação de crise social associada aos sentimentos de medo expressos no viver no contexto contemporâneo de violência urbana, a reflexão sobre a

\footnotetext{
20 "O lado individual (nos projetos de vida) é o das emoções. As minhas emoções estão ligadas, são matéria-prima e, de certa forma, constituem o projeto. Há sentimentos e emoção valorizados, tolerados ou condenados dentro de um grupo, de uma sociedade. Há, portanto maiores ou menores possibilidades de viabilizá-los, efetivá-los". (Velho apud Lins de Barros, 1998:155.)

${ }^{21}$ Como sugerem os trabalhos etnográficos em segmentos médios brasileiros de Velho (1979:22), Lins de Barros (1998:155) e Salem (1980).

${ }^{22}$ O artigo "O passado no presente: aos 70 falando do Rio de Janeiro" foi aqui, orientador de nossas reflexões. (Lins de Barros 1995: 92).

${ }^{23}$ Segundo Dumont, o "valor" designa algo diferente do "ser", algo que, distinto da verdade científica, que é universal, varia muito com o meio social e até no seio de uma sociedade dada, não só com as classes sociais mas, também, com diferentes setores de atividade e experiência (Dumont, 1985: 241).

${ }^{24}$ Propriedades de situação, conforme Evans-Pritchard, 1978.
} 
construção do individualismo no processo sócio-histórico moderno. O desejo idealizado da igualdade e emancipação do indivíduo moderno produz, na contraface, o "contágio da violência", o enfraquecimento da livre conduta e a impotência da produção de interações sociais que potencializem harmoniosamente a integridade moral e física de homens e mulheres no espaço público e privado, encerrando em seu âmbito o descompasso da ambiência humana perturbada e temerosa em seus atos recíprocos, cada vez mais fragmentados no enclausuramento do homem sobre si mesmo.

Trata-se de uma cultura do medo como transparece na narrativa de Dona Crista, apegada as suas reminiscências marcadas por uma nostalgia de um tempo embalado pelo sentimento de segurança, cotejado com seus temores atuais aos perigos impostos por uma violência urbana. $\mathrm{O}$ recolhimento doméstico pelo medo antecipado à ameaça de um perigo potencial frente à vulnerabilidade cotidiana impõe, de forma progressiva, não mais um individualismo-no-mundo como apregoava Louis Dumont (Dumont, 1985), mas um individualismo-recolhido e com medo-domundo, preso à suposta segurança do seu lar.

Ora, o sentimento de insegurança infere sobre as formas de sociabilidade cotidianas etnografadas (relações familiares, vizinhança, trabalho, parceiros, redes associativas formais clubes - e informais - footing - rede de amigos, lazer ou deslocamentos solitários e/ou utilitários, etc). Assim, em torno da inquietude e do sentimento de vulnerabilidade frente a possível experiência de vitimização, a simples preocupação se transforma de imediato em medo pessoal (Roché, 1993:67), motivando não só mudanças de atitudes nas formas das pessoas viverem e interagirem no mundo urbano contemporâneo mas igualmente na forma de atribuirem sentido a vida e representarem seu entendimento do mundo. Trata-se da ameaça da ruptura ética que aponta para um universalismo da boa-vontade, do respeito de si e da estima de si, onde o si "não é o eu. Trata-se, antes, de isolar o momento de universalidade que, na qualidade de ambição ou de pretensão - ... -, marca a experimentação pela norma do desejo de viver bem” (Ricoeur, 1991: 238 e 239).

Segundo Soares, "mais do que um problema tópico específico, a violência se converteu numa linguagem compartilhada, a partir da qual ... temos pensado os limites da sociabilidade, a sua crise e suas possibilidades" (Soares, 1995:1). O medo e a insegurança são, então, determinismos socializadores cada vez mais presentes no convívio urbano, uma linguagem compartilhada de forma cada vez mais coletiva.

Este processo está associado à tendência de qualificar todos os fenômenos que conotam violência a um mesmo e único processo, cuja matriz, simbolicamente compartilhada, seria a 
decadência da cidade, a degradação dos valores éticos, que geraria a crise da civilização urbana. É esta tendência a homogeneizar as observações relativas a fenômenos associados à violência a uma crise que Soares (1995:4) define por cultura do medo.

O sentimento de insegurança é mordaz, solapa a sociabilidade e as experiências públicas. A crise aparece mais aguda pela emergência da cultura do medo à vitimização, justamente na contramão da ideologia da emancipação das vigas sólidas da disciplina moral, da conduta econômica que erigiram a família nuclear nos dois últimos séculos de industrialização e urbanização. O paradoxo é temer o usufruto dos direitos à liberdade de ir e vir ou o de trilhar "um caminho de mudanças sociais concernentes a um campo social mais amplo do que aquele de sua própria família" (Lins de Barros, 1987:11), onde a própria diferença atribuída tradicionalmente aos papéis masculinos e femininos são questionados e ressemantizados subvertendo estruturas disciplinares no seio da instituição familiar, que "se emancipa das amarras da pudícia vitoriana, onde a personalidade individuada ensaia determinar os destinos da cultura" (Carvalho, 1995: 46).

A violência desenfreada que a todos indigna e aterroriza parece trair os atores da história da emancipação de ordens e proibições sócio-morais inculcadas durante tantos séculos, que conquistaram a queda de medos e opressões subjugadas pela ordem tradicional e a superação de traumas morais, de sentimentos de vergonha e constrangimentos associados aos atos afetivos, ações de ser-no-mundo compondo novas formas de relacionamento familiar, liberadas dos controles morais. Constrangimentos sociais bastante presentes nas narrativas, ao relacionarem suas experiências pessoais e familiares à modernização da sociedade, as transformações dos valores morais e modelos de conduta familiar.

Agora as trajetórias das vidas pessoais de cada indivíduo gravitam numa ambiência de agressões crescentes que avassalam suas previsibilidades, obrigando-os a espreitar suas práticas sociais num quadro de probabilidades em relação à violência urbana que empresta a imagem de uma sujeição a formas individualizadas de vitimização.

Hoje, caminhar, passar, viver, pertencer, ocupar são verbos condicionados pela imagem que as pessoas interiorizam e representam sobre os espaços urbanos de maior ou menor segurança. Paliativos de toda ordem são tomados em conta, cuidado com os horários sobretudo noturnos: segura-se o carro, a casa, vigia-se o bairro, etc. De fato a busca por maior segurança é uma empreitada sem fim.

Há, neste contexto de discursividades, uma construção social do medo. O medo do atentado ao patrimônio, à integridade física e o medo da morte por vitimização são sintetizados no temor à 
violência, ao crime, que tem como atitude paliativa um regramento de condutas, interiorizando a hostilidade do viver urbano, alienando-os de dinâmicas do mundo social. O receio resulta de um processo de contato agressivo a partir do outro que desestimula o indivíduo no que lhe é constitutivo: as interações que lhe constrói como sujeito social. Reféns do estranhamento, indivíduos em suas redes de pertencimento designam como perigosos territorialidades, trajetos, situações, horários, e indivíduos que, potencialmente estranhos, ameaçam a ordem social. A desconfiança do outro os mergulha no sentimento de esvaziamento dos sentidos coletivos, fortalecendo ainda mais as bases de um ethos social hiperindividualista.

\section{Da arte de viver o cotidiano inseguro}

A este estado de crise e ameaça da ordem coletiva, moradores, habitantes, cidadãos se vêem constrangidos a buscar estratégias e formas de viver enfrentamentos, táticas ${ }^{25}$ de reagir à crise e a violência que os anestesia. Respostas práticas e simbólicas para garantir a integridade humana e sociabilidades que expressam um novo estilo de vida, reconfigurando o imaginário social.

Daí esta possível leitura, entre outras, da arte de viver o cotidiano a partir das práticas que vão estetizando novas formas do viver e estilizando as interações sociais cotidianas propulsoras de expressões múltiplas de repensar e re-agir na cidade dramatizada pela estética do medo, nas condutas preventivas e projetivas por uma rotina segura, percursos e situações planejadas, trajetórias e interações comedidas, implicando uma "estética de existência", como diria Foucault (1984), delineada pela violência urbana como um constrangimento social externo.

No ato de narrar suas rememorações configurando o mapa dos medos, os velhos habitantes de Porto Alegre situam suas experiências com o mundo através deste sentimento ou de sua superação, seja na representação dos aspectos positivos, seja na dos negativos, conforme situações vividas e contextualizadas etnograficamente.

A análise, nesta instância, consiste em relacionar as formas com que experienciam as reconfigurações do envelhecimento a partir de múltiplas vivências que vitalizam este ciclo de vida às vicissitudes figuradas por uma violência urbana que estetiza os estilos de viver urbano.

Trata-se de dar conta das formas de reinventar o cotidiano apontadas em seus relatos que sinalizam para a emergência progressiva de uma massa de indivíduos idosos (como apontam as estatíticas sobre os ganhos tecnológicos e científicos, medicina gerontológica, por exemplo, neste final de século) no âmbito das novas imagens construídas sobre o ser velho, que ao contrário do

\footnotetext{
${ }^{25}$ Sobre o conceito de tática recorrer a De Certeau, 1994.
} 
idoso construído pelo discurso gerontológico, multifacetam o desempenho de papéis previstos socialmente para os velhos. O próprio convívio familiar, neste sentido se desamarra de antigos preceitos para serem revistos sob novas perspectivas. As experiências são múltiplas tanto quanto são os indivíduos singulares, mas o exercício destas novas re-interpretações da realidade acabam por mapear um estilo de viver a dramática do envelhecer sob novas figurações.que emancipam os atores e possibilitam a negociação possível seja de suas autonomias, seja de seus pertencimentos coletivos. Este movimento não é demonstrativo de uma luta contra a família, ou da "crise familiar" que instituições morais buscam convencer, nem se revela uma luta contra as desigualdades de gênero (proposta do movimento feminista, por exemplo), bem como não se reduz as ações e práticas que celebram o envelhecimento como os "programas para a terceira idade ou os grupos de convivência de idosos" que tem "na mídia o palco central para a criação e divulgação das novas imagens" (Debert, 1999: 209).

Nosso propósito é acionar este campo interpretativo das múltiplas experiências de envelhecer que não apenas elucidam sobre um projeto reflexivo do eu, mas consubstancialmente valorizam a experiência e o saber de ser um sujeito com memória do seu eu, do seu grupo, de sua cidade onde ele próprio é sujeito configurador de uma história coletiva. Os acontecimentos cotidianos não lhes parecem assim alheios de seus jogos de memória e fluxos de vida. Não se trata também de rejuvenescer o lugar (o país, a cidade, sua família) a partir da cultivação da memória do social, que reduziria, a qualidade narrativa a partir do lugar de velho habitante, ao santuário da preservação e conservação de referências identitárias emblemáticas.

A adesão a estética do medo não impede o aproveitamento de formas de sociabilidade privilegiadas para a valorização pessoal e afetiva, como relata Seu Mauro ao cultivar grupos de amigos em reuniões semanais, tanto quanto motiva `a vivência da prática religiosa já tradicionais na cultura brasileira como o catolicismo, ou a adesão à formas religiosas mais recentes no ethos brasileiro como a opção espiritual de Dona Raquel.

Ser porto alegrense para o velho habitante narrador, não é afundar-se nos traços de um passado perdido. Mas é enquanto velho habitante que pode delinear os múltiplos movimentos que lhe assujeitam a conflitos e tensões pessoais/coletivos, internos/externos, singulares/complexos em que negocia incessantemente uma identidade familiar e social, individual e coletiva.

Ser velho é viver um conflito de identidade e ser velho habitante de Porto Alegre, é igualmente viver as tensões identitárias que a cidade amalgama. Conflitos que descompassam a rítmica das trajetórias de vida e do trajeto urbano (história da cidade), mas que não matam a 
reinventividade do viver neste ethos. É a partir da identidade de velhos habitantes que podem então narrar sua cidade, enfim, trabalhar a memória tecendo as "reminiscências" que re-situam as experiências orientadas pelo sentimento do medo como algo vivido, temporalizando a vida por esta identidade-"valor", onde se percebem como sujeitos transformados na predominância de outros valores significativos ao passado. Mas, tocados pelas circunstâncias, nos jogos da memória os velhos habitantes vão singularizando estas mobilidades desconcertantes impressas por condições externas e acabam por conferir ao próprio ato de memorar uma poética temporal na vigília pelo aprendizado de reinventar a vida por reordenações dos sentidos fragmentados ou, como diria De Certeau, "na arte de contar as maneiras de fazer, estas se exercem por si mesmas" (De Certeau, 1994: 166).

Compartilhar da cultura do medo que se impõe pela linguagem ordinária, e que naturaliza seu conteúdo, acaba por permitir o conhecimento deste processo e ultrapassá-lo, não na negação mas na adesão a esta realidade, no reconhecimento da existência do conflito na dramatização das relações sociais. Compreender nossa relação com a cultura do medo seria, de certa forma, conhecer nossa tática de pensar a morte para desejar a vida. Não se trata de criar a expectativa de prorrogar a morte fisiológica, mas de ultrapassar as rupturas trágicas, que ameaçam de esquecimento, as referências de uma duração da identidade do grupo.

Desta forma, se a violência nos situa no drama trágico da vida pela sua dinâmica cíclica como determinante simbólico, a cultura do medo como crise nos situa num jogo interativo, dialógico e reflexivo que acaba por permitir, em alguma dimensão, o conhecimento do si-mesmo. Uma circunstância que nos faz ver a cidade inventada por nós mesmos, uma trajetória de vida traçada pelo nosso desejo e temores constituídos por nossos ressentimentos.

As narrativas que delineiam fragmentos de trajetórias são apreendidas como prospecção e projeção das possibilidades de realização de um projeto de humanidade. Se o aceleramento dos acontecimentos urbanos entrelaça a violência que escapa à legibilidade, o medo à vitimização nos ameaça como condição de possibilidade de um desconhecimento do outro e de esquecimento das práticas conciliadoras de redes de sentido.

\section{Conclusão}

Os conflitos, as crises, as tensões do mundo moderno têm sido historicamente vinculadas ao fenômeno urbano, contexto que implica compreender a vida e as interações sociais diferenciadas em graus de concretude e vividez. 
Frente a um aumento desmesurado da violência nas grandes cidades, a questão da sobrevivência assumiu aspectos especialmente dramáticos, como sugere Gilberto Velho: "Pode-se especular que essas seriam variáveis importantes para compreender uma espécie de individualismo agonístico que se tornou cada vez mais freqüente nas camadas médias brasileiras"26.

Pensar a condição de viver na cidade hoje, infere sobre as formas culturais e simbólicas dinamizadas igualmente por sentimentos de medo, insegurança, ansiedade e solidão, mapeando a cidade como um grande depositório de vítimas de um contexto urbano ameaçado pelas crises, violência, fragmentações, esquecimentos, etc. O sentimento de inseguranças não encontra eco nas eventuais providências político-administrativas estatais, na maioria das vezes insuficientes.

Frente à ineficiência do aparelho estatal para limitar esta onda de ameaças (uma vez que em grande parte o próprio aparelho e sistema estatal é corrompido: polícia, políticos, etc) temerosos ou não, os habitantes tomam precauções, atitudes, comportamentos que inferem em práticas e sociabilidades cotidianas.

O cenário da cidade se confirma, assim, como topos de uma multiplicidade de acontecimentos individuais e coletivos que denotam experiências vividas carregadas de sentimento de insegurança. Este sentimento é, sem dúvida, uma sensação que envolve uma série de aspectos psicológicos e culturais dos indivíduos, suas emoções, suas reflexões e seus comportamentos.

Tendo os indivíduos sido vítimas de situações de violência urbana ou simplesmente bombardeados pela mídia, sua reclusão passa a ser uma atitude recorrente, desconfiando de suas próprias certezas sobre a previsibilidade de sua "sorte" em seus movimentos interativos em redes diversas no mundo urbano. A previsibilidade lhe escapa "das mãos", ou do seu pensamento, para ser tomado pelo temor à imprevisibilidade que a condição da violência urbana impõe.

O medo estruturante é o de sair em espaço público, sobretudo em determinado horário. A insegurança concerne a todos, mas aos idosos esta condição parece mais perversa, sobretudo no final do seu ciclo de vida, em geral mais solitário, tendo que contar com os imponderáveis do corpo envelhecido. Os idosos de segmentos médios que optam pela autonomia residencial aderem aos “conselhos" de prevenção que configuram os "medos domésticos" (Roché 1993) como o de trancarse em casa "a sete chaves", o não-atendimento à porta, o aumento à proteção do domicílio. A vida intra-muros não é um desejo, mas uma prevenção para evitar a vitimização. Os recursos possíveis do pertencimento à segmento médio, é investido na segurança material em que a grade e o alambrado se destacam na arte da proteção.

\footnotetext{
${ }^{26}$ Velho. 1987. p. 4.
} 
A vida social no mundo público não é rompido, pois nutre-se nele como ser social, mas sua interação neste é de receio, medo do estranho, medo do assalto, medo dos muitos acidentes de percurso e das armadilhas à que está sujeito na condição cotidiana, numa espécie de agorafobia. Ambas as formas de configurar as inquietudes são correlatas com a expressão de um medo que se afirma na subjetividade -“eu estou inseguro” - (Roché 1993:150). Estas formas de expressão das preocupações que habitam os corações e as mentes dos citadinos se colocam como uma discursividade (um texto) do desejo coletivo de uma re-construção de uma ordem perdida, de uma normatividade desfeita, de uma sociedade que lhes parece cada vez mais estranha e incivilizada, buscando incessantemente, no contexto da imponderabilidade, os sentidos de seguir.

Serão, de modo geral, as vozes citadinas dos segmentos médios, movidos pela lógica do autointeresse, que aclamarão a incivilidade que retrata a violência urbana, que ressoa em suas avaliações sobre a perda dos valores morais, o esvaziamento de sentido ético, a desordem e o desencantamento das emoções humanas, a banalização do horror, a subversão dos direitos, a saturação (ou excessos) dos modelos de gestão política da ordem social, a guerra civil.

Os constrangimentos impostos pela violência, dirão os velhos habitantes de Porto Alegre, tensionam os valores modernos na perda de referências humanitárias, a reciprocidade, a solidariedade encapsuladas num tempo alhures, designando às estruturas de poder político-urbanas a tarefa de salvaguarda do mundo objetivado da lógica racionalista a partir de atos e normas coibidoras da criminalidade.

Nas experiências de vida dos entrevistados nesta cidade, o sentimento de medo é constitutivo de uma crise que desancora as probabilidades de suas projeções de vida. A clivagem de suas vontades e escolhas não pode mais seguir apenas um traçado livre da ideologia individualista, mas precisa conformar suas volições ao mapa do medo. A “crise dos tempos”, presente para a população etnografada é a ruptura do trajeto de identificação do indivíduo psicológico como o sujeito da consciência, da vontade e autonomia, sobretudo ao condicionar o futuro dos netos a um mundo cotidiano que não garante mais uma previsibilidade da vida, de reconhecimento do outro na imagem ideal do prometeico (trabalhador honesto).

Neste contexto de cultura do medo, o citadino tende a aguardar macro reestruturações com eficácia para a garantia de uma qualidade de vida humana, cultivando em suas impressões do viver urbano, as crises dos tempos gestadas nos discursos mediáticos que acabam por imprimir códigos de interpretação da realidade.

Mas na incessante arte de narrar sua cidade, os velhos habitantes acabam por transmitir formas 
de ultrapassar a passividade de nossos sentimentos urbanos de desencantamento. É nesse sentido que buscou-se a narrativa "de durar" na cidade em que viveram, este trabalho árduo de não deixar cair no esquecimento as "artes de fazer" o social, dado que, o trabalho da memória, de lembrar o que não esquecemos, tem esta força de reconstruir as razões afetivas para continuar. ${ }^{27}$

\section{Referencias}

ARENDT, H. Sobre a violência. Rio de Janeiro: Relume Dumará, 1994.

BACHELARD, G. La dialectique de la durée. Paris: Quadrige/PUF, 1989.

BENJAMIN, W. "Critica da violência - critica do poder". In: Documentos De Cultura - Documentos de Barbarie (Escritos Escolhidos). São Paulo: Cultrix, EDU São Paulo, 1986.

BENJAMIN, W. Charles Baudelaire um lírico no auge do capitalismo. Obras Escolhidas III. São Paulo: Brasiliense, 1995.

BENJAMIN, W. Magia e técnica, arte e política. Ensaios sobre Literatura e Historia da Cultura. São Paulo: Brasiliense, 1993.

BERMAN, M. Tudo que é solido desmancha no ar: a aventura da modernidade. São Paulo: Cia. das Letras, 1987.

BOSI, E. Memória e sociedade. Lembranças de velhos. São Paulo: Queiroz ED. Ltda. e EDUSP, 1987.

BOTT, E. Família e rede social. Rio de Janeiro: Francisco Alves, 1976.

BOURDIEU, P. A economia das trocas simbólicas. São Paulo: Perspectiva, 1974. p. 3 a 26.

CANEVACCI, M. A cidade polifônica. Ensaio sobre a antropologia da comunicação urbana. São Paulo: Studio Novel, 1993.

D'AVILA, N. L. M.. "Na trajetória da modernidade, as camadas médias porto-alegrenses frente à modernização na década de 50". Dissertação de mestrado no PG em História. Porto Alegre: UFRGS, abril de 1996.

DA MATTA, R. A Casa \& Rua. Espaço, cidadania, mulher e morte no Brasil. São Paulo: Brasiliense, 1985.

DE CERTEAU, M. A invenção do cotidiano: artes de fazer. Petrópolis: Vozes, 1994.

DEBERT, G. G (Org). Antropologia e Velhice. Textos Didátiocs, Campinas: IFCH/UNICAMP, n. 13, março de 1994.

DEBERT, G. G. A reinvenção da velhice. São Paulo: Edusp, Fapesp, 1999.

DELUMEAU, J. História do medo no Ocidente. 1300-1800. São Paulo: Companhia das Letras, 1989 .

DUVIGNAUD, J. Festas e civilizações. Fortaleza: EUF/Ceará e Tempo Brasileiro, 1983.

DIAS DUARTE, L. F.. Da vida nervosa, nas classes trabalhadoras urbanas. Rio Janeiro: J. Zahar./CNPq, 1986.

DUMONT, L. O individualismo. Uma perspectiva antropológica da ideologia moderna. Rio de Janeiro: Rocco, 1985.

ELIAS, N. A sociedade dos indivíduos. Rio de Janeiro: Jorge Zahar, 1994.

EVANS-PRITCHARD, E.E. Os Nuer. São Paulo: Perspectiva, 1978.

FOUCAULT, M. Microfisica do Poder. Rio de Janeiro: Graal, 1979.

FOUCAULT, M. Vigiar e Punir. Petrópolis: Vozes, 1988.

GANDILLAC, M. de. Gêneses da modernidade. Rio de Janeiro: Ed. 34, 1995.

GEERTZ, C. A interpretação das culturas. Rio de Janeiro: Zahar, 1978.

\footnotetext{
${ }^{27}$ Seguimos Bachelard, 1989.
} 
GIDDENS, A. As conseqüências da modernidade. São Paulo: UNESP, 1991.

GOFFMAN, E. La mise en scène de la vie quotidienne. Paris, De Minuit, 1973.

GRAFMEYER, Y. et JOSEPH, I. L'Ecole de Chicago. Naissance de l'écologie urbaine. Paris: Aubier Montaigne, 1984.

HALBWACHS, M. La mémoire colletive. Paris: Puf, 1968.

HARVEY, David. Condição pós-moderna. São Paulo: Loyola, 1996.

ISRAEL, Joachim. "Simmel et quelques problèmes fondamentaux de la connaissance". In: Revue Société. Georg Simmel. Paris: Dunod. 1992.

JACOBS, J. Morte e vida de grandes cidades. São Paulo: Martins Fontes, 2000.

LASCH, C. The culture of narcisism: american life in the age of diminishing expectations. New York: Mouton, 1978.

LINS DE BARROS, M. “O passado no presente: aos 70 falando do Rio de Janeiro". In: Cadernos de Antropologia e Imagem, A cidade em Imagens, número 4, Rio de Janeiro: UERJ, NAI, 1995.

LINS DE BARROS, M. Autoridade \& Afeto. Rio de Janeiro: Jorge Zahar, 1987.

MAUSS, M. Sociologia e Antropologia. São Paulo: EPU, EDUSP, 1974.

MILLS, C W. A imaginação sociológica. Rio de Janeiro: Zahar, 1975.

RICOEUR, p. Interpretação e ideologias. Rio de Janeiro: Francisco Alves, 1988.

RICOEUR, P. O si-mesmo como um outro. Campinas: Papirus, 1991.

RICOEUR, P. Tempo e Narrativa, tomo I e II. Campinas: Papirus, 1994.

ROCHE, S. Le sentiment d'insécurité. Paris: Puf, 1993.

ROVINSKI, S L R. "A violência na vitimização criminal - vivências em situações de assalto". Dissertação de mestrado, Instituto de Psicologia. Porto Alegre: PUCRS, dezembro de 1993.

SALEM, T. Um estudo de papéis e conflitos familiares. Petrópolis: Vozes, 1980.

SALEM, T. “A 'despossessão subjetiva': dos paradoxos do individualismo”. In: Revista Brasileira de Ciências Sociais, número 18, ano 7, fevereiro de 1992. Rio de Janeiro: Relume Dumará. p. 62 a 77.

SENNET, R. O declínio do homem público. São Paulo: CIA. das Letras, 1988.

SENNETT, R. Les tyrannies de l'intimité. Paris: Seuil, 1979.

SIMMEL, J. Cultura femenina y otros ensayos. Madrid: Revista de Occidente, 1934.

SOARES, L E. "Homicídios Dolosos Praticados contra Menores no Estado do Rio de Janeiro. Relatório de pesquisa desenvolvido como parte do plano de trabalho do Projeto Se Essa Rua Fosse Minha". Rio de Janeiro: FASE, IBASE, IDAC, ISER, 1991.

SOARES, L E. "Violência e cultura do medo no Rio de Janeiro". Mimeog. Palestra proferida no PPG Antropologia Social. Porto Alegre: UFRGS, março 1995.

SOARES, L.E. et alli. Violência e política no Rio de Janeiro. Rio de Janeiro: RelumeDumará/ISER, 1996.

SOREL, G. Reflexões sobre a Violência. Petrópolis: Vozes, 1993.

TIRELLI, C. "Cartografia social da violência: estudo sobre a criminalidade na Região Metropolitana de Porto Alegre 1988 à 1995. Dissertação de Mestrado, PPGS. Porto Alegre: UFRGS, dezembro de 1996.

TURNER, Victor. "Social Dramas and Ritual Metaphors". In: Dramas fields and metaphors: symbolic action in Human Society. Itacha: Cornell University Press, 1974.

VELHO, G et FIGUEIRA, S (coordenadores). Família, Psicologia e Sociedade. Rio de Janeiro: Campus, 1981.

VELHO, G. "O cotidiano da violência: identidade e sobrevivência". In: Boletim do Museu nacional. Nova serie. Rio de Janeiro: Antropologia n ${ }^{\circ} 56$ - 30 de abril de 1987.

VELHO, G. Individualismo e cultura. Notas para uma antropologia da sociedade contemporânea. Rio de Janeiro: Zahar, 1981. 
VELHO, G. Subjetividade e sociedade. Rio de Janeiro: Zahar, 1986.

VELHO, O (organizador). O fenômeno urbano. Rio de Janeiro: Zahar, 1979.

WAGNER, H R. Textos Escolhidos de Alfred Schutz. Rio de Janeiro: Zahar, 1979.

WEBER, M. La ville. Paris: Aubier Montaigne, 1982.

ZALUAR, A. Condomínio do diabo. Rio de Janeiro: Revan e UFRJ, 1994. 